\title{
Humoral immune responses of the grouper Epinephelus akaara against the microsporidium Glugea epinephelusis
}

\author{
J. Y. Zhang ${ }^{1,4}$, Y. S. Wu ${ }^{2}$, H. B. Wu ${ }^{3}$, J. G. Wang ${ }^{1, *}$, A. H. Li ${ }^{1}$, M. Li ${ }^{2}$ \\ ${ }^{1}$ State Key Laboratory of Freshwater Ecology and Biotechnology, Institute of Hydrobiology, Chinese Academy of Sciences, \\ Wuhan, Hubei 430072, PR China \\ ${ }^{2}$ Institute of Tropical Medicine, The First Military Medical University, Guangzhou, Guangdong 510515, PR China \\ ${ }^{3}$ South China Sea Institute of Oceanology, Chinese Academy of Sciences, Guangzhou, Guangdong 510301, PR China \\ ${ }^{4}$ Graduate School of the Chinese Academy of Sciences, Beijing 100039, PR China
}

\begin{abstract}
The humoral immune responses of grouper Epinephelus akaara to a natural infection with Glugea epinephelusis was studied by ELISA utilizing intact mature spores as the coated antigen. Results showed that a specific humoral immune response was elicited, but the intensity of infection (in terms of the number of cysts) was not related to the antibody level in naturally infected hosts. The differences in the antigenicity of intact mature spores and soluble spore proteins derived from cracked mature spores were also analyzed. Results suggested that similar antigen epitopes existed between the 2 groups. Additionally, antigen component patterns and the distribution of antigen with immunogenicity were investigated by using the western blot and the immunofluorescent antibody technique (IFAT). The new parasitic microsporidium has specific polypeptide patterns comparable to the reported fish microsporidians. The main antigenic substances are concentrated on the surface of spores, and are mostly located on the anterior and posterior end of the spore bodies. Most surface components of the $G$. epinephelusis spores are soluble. The potential role of the surface components in initiating infection was also discussed.
\end{abstract}

KEY WORDS: Glugea epinephelusis · Microsporidia · Epinephelus akaara · Humoral immune responses · antigenicity

Resale or republication not permitted without written consent of the publisher

\section{INTRODUCTION}

Microsporidia are obligate intracellular parasites that infect many invertebrates and all 5 classes of vertebrate taxa as opportunistic pathogens. They mainly infect bony fish and insects. As yet there is a lack of effective licensed pharmacological or immunological control measures and therefore many commercially important cultured fish species are infected, resulting in severe economic losses (Roberts 2001, Zhang et al. 2004). In addition, the number of new hosts infected by the pathogen is increasing. A recent report that large numbers of cultured grouper Epinephelus akaara had died due to infection with a new microsoporidium in Dayawan, near Shenzhen in the
Guangdong province of China (Wu et al. 2004) attracted our attention as there have been few reports of severe fish microsporidiosis in China (Zhang et al. 2004). The authors placed it in the genus Glugea and termed it Glugea epinephelusis according to taxonomic and molecular characterizations based on small ribosomal RNA partial sequences.

Although immune responses of fish against microsporidians remain enigmatic (Laudan et al. 1986, 1987, Woo 1992, Leiro et al. 1993, 1997, Wongtavatchai et al. 1995, Kim et al. 1996, 1998, Pomport-Castillon et al. 1999), specific immune responses of fish, such as humoral, mucous and cellular immune responses, have been demonstrated in some species (Leiro et al. 1993, Hung et al. 1996, Kim et al. 1996, 1998). In the case of 
Glugea epinephelusis, immune responses of grouper against the infection, however, are still unknown. Immune responses are significant for hosts as a means of defense against parasites (Wakelin 1996). With the aim of investigating whether immune responses of Epinephelus akaara might be involved in controlling this new microsporidian infection and finding a practical immunological diagnosis and means of controlling the parasite, this study investigated the humoral responses of the host to a natural infection with the parasite. The antigenicity of the pathogen was also investigated.

\section{MATERIALS AND METHODS}

Fish. Thirty naturally heavily infected fish were obtained from a farm near Dayawan near Shenzhen in the Guangdong province of China. The prevalence of Glugea epinphelusis was above $90 \%$ based on the presence of Glugea cysts (xenoma) as estimated by the naked eye after dissection of the fish. All fish were divided into 2 groups according to the severity of infection determined on the basis of the number of cysts noted. Fish with over 500 cysts were classified heavily infected, and the remaining individuals constituted the other group. Sixteen clinically healthy fish were purchased as a control group from another commercial farm which had no records of microsporidian infection. No significant differences in size and body weight existed between control and experimented individuals. All fish were killed with an overdose of tricaine methanesulfonate (MS-222). Blood was drawn from the caudal vein of all individuals. Serum was prepared by standard methods (Zhu \& Feng 1994) and stored at $-70^{\circ} \mathrm{C}$ until used.

Isolation and purification of spores. Glugea epinephelusis spores were isolated and purified from heavily infected Epinephelus akaara using methods described by Delbac et al. (1998) with some modifications. Briefly, black cysts were collected from the abdominal cavity of infected fish, and washed twice using phosphate buffered saline (PBS, pH 7.4), then homogenized by means of a glass homogenizer. The suspension was passed through 2 layers of gauze and then filtered through a $100 \mu \mathrm{m}$ mesh to eliminate large pieces of tissue debris. Purification of spores was performed through continuous sucrose gradients $(1: 1$, $1: 2,1: 3,1: 4,1: 5,1: 6, \mathrm{v} / \mathrm{v})$ centrifugation at $800 \times g$ for $20 \mathrm{~min}$ at $4^{\circ} \mathrm{C}$. The area containing spores was removed carefully and washed 3 times with PBS and centrifuged at $1500 \times g$ for $10 \mathrm{~min}$ at $4^{\circ} \mathrm{C}$. Spores concentration was adjusted to $1 \times 10^{9}$ spores $\mathrm{ml}^{-1}$ using a hemocytometer. The spores were stored at $4^{\circ} \mathrm{C}$ in distilled PBS containing penicillin and streptomycin (15 $\mathrm{U} \mathrm{ml}^{-1}$ ) until required.
Preparation of spore antigens and mouse polyclonal antibodies. Soluble spore antigens were prepared using methods reported by Hung et al. (1996) with some modifications. One ml aliquots of Glugea epinephelusis spores suspension $\left(1 \times 10^{9}\right.$ spores $\mathrm{ml}^{-1}$ PBS) were processed by 10 freeze-thaw cycles of liquid nitrogen and skived by means of a mortar. The supernatants of the soluble spore proteins were collected by centrifugation at $3000 \mathrm{~g}$ for $10 \mathrm{~min}$ at $4^{\circ} \mathrm{C}$. The soluble spore protein was concentrated to $1 \mathrm{mg} \mathrm{ml}^{-1}$ by dialyzing and stored at $-70^{\circ} \mathrm{C}$ until needed. Two Kunming strain mice were immunized 3 times subcutaneously using the soluble spore proteins (400 $\mu \mathrm{g}$ in PBS) and intact mature spores $\left(1 \times 10^{7}\right.$ spores in PBS $)$ emulsified with $200 \mu$ adjuvant respectivily to prepare mouse anti-serum according to Zhu \& Feng (1994). Freund's complete adjuvant was used for the first immunization and Freund's incomplete adjuvant for the following 2 times.

Enzyme-linked immunoabsorbent assay (ELISA). The ELISA procedure of Leiro et al. (1993) was applied to detect antibody responses of naturally infected Epinephelus akaara against Glugea epinephelusis utilizing intact mature spores as the coated antigen. Briefly, $100 \mu \mathrm{l}$ aliquots of $G$. epinephelusis spore suspension $\left(1 \times 10^{6}\right.$ spores $\left.\mathrm{ml}^{-1} \mathrm{PBS}\right)$ were added to a 96 well microtitration plate (Poly Sorp, Nunc) previously coated with $100 \mu \mathrm{l}$ of $0.01 \%$ Poly-L-Lysine (Sigma) solution (in PBS) for $2 \mathrm{~h}$ at room temperature (RT). After incubation for $2 \mathrm{~h}$ at RT, the plates were washed 5 times with $0.01 \mathrm{M}$ PBS containing $0.5 \%$ (vv) Tween 20 (PBST) and blocked with PBS containing $3 \%(\mathrm{w} / \mathrm{v})$ fatfree milk (blocked buffer ) for $1 \mathrm{~h}$ at $37^{\circ} \mathrm{C}$ and then washed 3 times using PBST. One hundred $\mu$ l aliquots of grouper serum diluted by 1:500 in PBS were added to the plates. After incubation overnight at $4{ }^{\circ} \mathrm{C}$ and 5 washes with PBST, $100 \mu \mathrm{l}$ of mouse anti-grouper Epinephelus spp. IgM (ADL) diluted (1:2000) in PBS as added to each well, and the plates were incubated for $2 \mathrm{~h}$ at RT. Then $100 \mu \mathrm{l}$ of horseradish peroxidase (HRP)-labeled goat anti-mouse IgG (GAM) (Boster) diluted (1:5000) in PBS as added to each well. After incubating for $2 \mathrm{~h}$ at RT and washing 5 times, $150 \mu \mathrm{l}$ of $3,3,5,5^{\prime}$-tetra-methyl benzidine (TMB) was added to each well as the chromogen for color development. After $15 \mathrm{~min}$, the reaction was stopped with $2 \mathrm{M}$ $\mathrm{H}_{2} \mathrm{SO}_{4}$, and optical density at $450\left(\mathrm{OD}_{450}\right)$ was measured by a plate reader (Bio-Rad). Sera from clinically health fish were used as a control.

To examine whether different epitopes on spores or in soluble antigens were recognized by mouse serum, an indirect-ELISA was performed (Leiro et al. 1993, Zhu \& Feng 1994). Serum from spore-immunized mice was incubated with soluble antigen and vice versa. Normal mouse serum was used as a negative control 
and bovine serum albumin (BSA) as a blank control. A ratio of sample OD/control OD was calculated. A ratio above 9 was considered as a strong response (++), 9 to 5 medium (+) and below 2, no response (-).

Sodium dodecyl sulphate-polyacrylamide gel electrophoresis (SDS-PAGE) and western blot analysis. Four hundred $\mu \mathrm{l}$ aliquots of purified spores suspension $\left(1 \times 10^{7}\right.$ spores $\left.\mathrm{ml}^{-1}\right)$ and soluble spore proteins solution $\left(0.5 \mathrm{mg} \mathrm{ml}^{-1}\right)$ treated by $2 \times$ SDS sample buffer were visualized using SDS-PAGE using standard methods (Sambrook et al. 1989). A prestained molecular weight with a range from 14.4 to $97.4 \mathrm{kDa}$ (Promega) was used to estimate the molecular weight of protein bands separated by SDS-PAGE. Gels were stained for $12 \mathrm{~h}$ with $0.01 \%$ Coomassie Bright Blue R-250 (Rio-Rad). Western blot was performed using the method described by Irby et al. (1986) and Hung et al. (1996). The pooled sera of naturally infected fishes diluted (1:100) in blocked buffer, mouse anti-grouper Epinephelus spp. IgM (ADL) diluted (1:1000) in blocked buffer, GAM (Boster) diluted (1:1000) in blocked buffer were used as the first antibody, second antibody and third antibody respectively. Pooled serum from a clinically healthy sample was used as a negative control.

Indirect fluorescent antibody technique (IFAT). To examine the distribution of predominant antigenic materials, an indirect fluorescent antibody technique (IFAT) was applied as described by Kawamura (1977). A suspension of intact spores was smeared on a glass slide and dried at RT. Then the smears were fixed in $10 \%(\mathrm{v} / \mathrm{v})$ methanol for $20 \mathrm{~min}$ before rinsing in PBS (pH 8.0) 3 times. Infected fish anti-serum was diluted $(1: 100)$ in PBS and used as the first antibody. Mouse anti-grouper Epinephelus spp. IgM (ADL) diluted (1:1000) in PBS and fluorescein isothiocyanate (FITC)labeled GAM serum (Boster) diluted (1:64) in PBS were added to the smears and incubated at $37^{\circ} \mathrm{C}$ for $20 \mathrm{~min}$ successively. The smears were finally examined under a fluorescence microscope (Olympus). Pooled serum of the clinically healthy sample was used as a negative control.

\section{RESULTS}

\section{Analysis of naturally infected Epinephelus akaara antibody by ELISA}

Heavily infected fish could be detected by external symptoms, including slow movements and swelling of the abdominal cavity, but there were no other obvious signs of infection. Most infected individuals did not show any external symptoms, but large numbers of black cysts, which looked like concretions, were found in the abdominal cavity after dissection (Fig. 1). The group with more than 500 cysts displayed a mean ELISA value of $1.017 \pm 0.041$; the group with less than 500 cysts displayed $1.008 \pm 0.057$, but the clinically healthy fish had a mean value of only $0.109 \pm 0.008$ (Fig. 2). As also shown in Fig. 2, the differences in the immune responses of individuals of naturally infected sample against the pathogen existed, but were not significant $(p>0.05)$. Indirect-ELISA indicated that sera from immunized spores can cross-react with soluble spore protein and vice versa (Table 1) although the intensity of the responses was not identical.

\section{SDS-PAGE and western blot analysis}

More than 20 distinct protein bands could be recognized by $10 \%$ SDS-PAGE from intact mature spores and the polypeptide profiles were mainly between 18 and $88 \mathrm{kDa}$. However, a band with a molecular weight of about $37 \mathrm{kDa}$ was clearly visualized when the soluble spore proteins were analyzed, although many vague bands below $17 \mathrm{kDa}$ were also revealed. Western blot showed that at least 9 of these proteins bands with molecular weights of about 15, 21, 23, 27, 37, 40, 74,82 and $110 \mathrm{kDa}$ (Fig. 3) for the 2 groups can be recognized by anti-serum of Epinephelus akaara. Interestingly, western blot showed that the protein patterns of soluble spore protein and intact mature spores recognized were nearly identical.

\section{Distribution of antigen components by IFAT}

IFAT showed that the main antigenic materials were located on the surface of spores (Fig. 4). The strong fluorescence was concentrated on the anterior and poste-

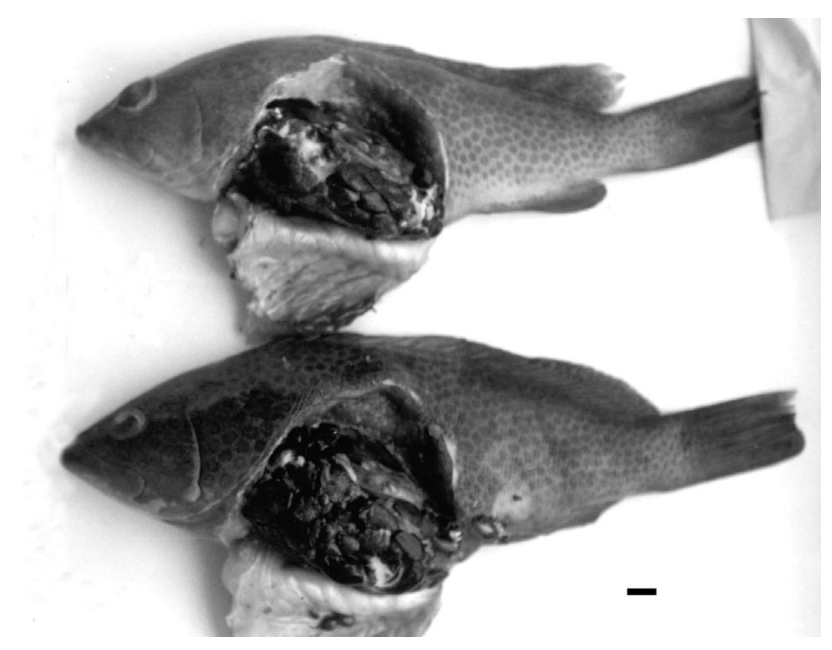

Fig. 1. Epinephelus akaara infected with Glugea epinephelusis, showing black cysts in the abdominal cavity. Scale bar $=1 \mathrm{~cm}$ 


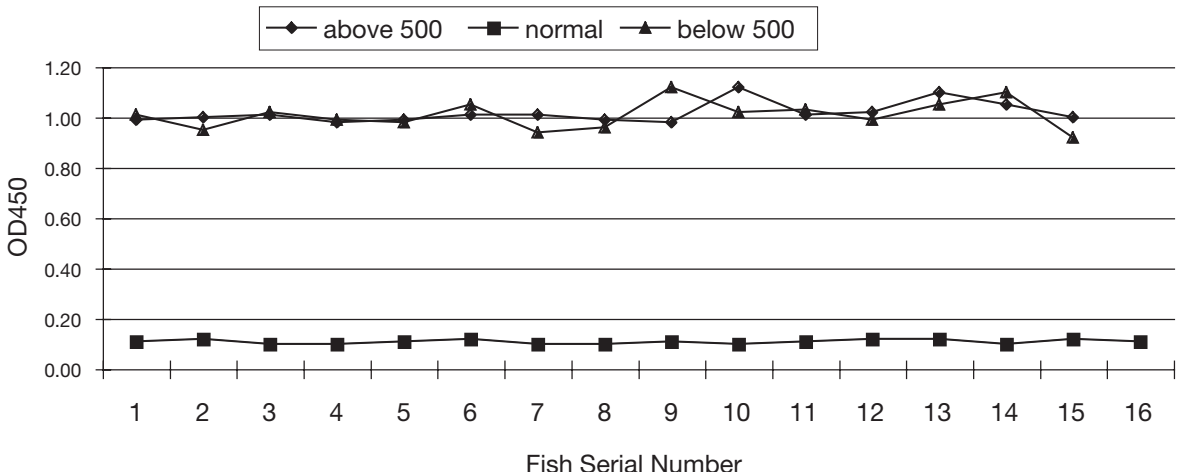

Fig. 2. Epinephelus akaara infected by Glugea epinephelusis. Antibody responses of naturally infected groupers against $G$. epinephelusis by ELISA. See text for details
Table 1. Glugea epinephelusis infecting Epinephelus akaara. Comparison of antigenicity differences of intact spore and soluble spore proteins.,,+++- : strong, medium and no definite responses

\begin{tabular}{|lccc|}
\hline & $\begin{array}{c}\text { Anti-intact } \\
\text { spores }\end{array}$ & $\begin{array}{c}\text { Anti-soluble } \\
\text { proteins }\end{array}$ & $\begin{array}{c}\text { Normal } \\
\text { serum }\end{array}$ \\
\hline Intact spores & ++ & + & - \\
Soluble spores & + & ++ & - \\
\hline
\end{tabular}

rior end of the spores' wall. However, very weak fluorescence was displayed when using the serum derived from clinically healthy fish (data not shown).

\section{DISSCUSSION}

The grouper Epinephelus akaara is an important cultured breed in China and severe economic losses were caused by infection with Glugea epinephelusis (Wu et al. 2004). As chemotherapeutic treatment is not available, extensive studies have been carried out on immunological control and prophylactic vaccination against microsporidians infection (Zhang et al. 2004). Much work has been done to determine the immune response of fish against microsporidians, and 2 distinct views have emerged. Some authors believe that fish infected by microsporidians can generated a specific immune response against the pathogen (Leiro et al. 1993, Hung et al. 1996, 1997, Kim et al. 1996, 1998, 1999). However, it was also widely accepted that the parasite can evade the host's immune defense mechanism by mimicing or adsorbing host antigens, which can result in immunosuppression of the host for other pathogens (Laudan et al. 1986, 1987, Wongtavatchai et al. 1995, Kim et al. 1998). The experiments conducted in this study revealed that the naturally infected group had a significantly higher anti-G. epinephelusis ELISA value than the clinically healthy group, approximately 10 times higher $(p<0.01)$. In other words, the surface antigens of G. epinephelusis can be recognized specially by E. akaara and a significant humoral immune response was elicited, although we do not know the definitive components of the recognized antigen. In addition, there are differences in the immune response among individuals of naturally infected grouper against the pathogen, but they are not significant ( $p>$ 0.05 ). This suggests that a specific humoral immune response of $E$. akaara was elicited by infection with $G$. epinephelusis and the intensity of the infection was not related to the antibody level in naturally infected grouper using intact mature spores as a coated antigen. It is similar to that reported by Kim et al. (1996).

The similar antigen epitopes recognized by mouse anti-serum existed between mature spores and soluble spore proteins, which seems to suggest that some conserved proteins are retained when pansporoblast differentiate into valvogenic cells, capsulogenic cells
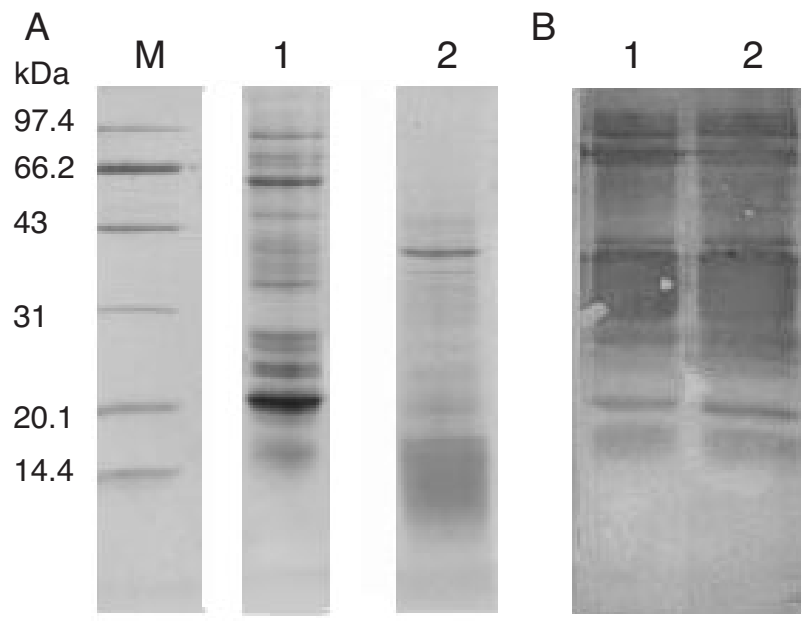

Fig. 3. (A) SDS-PAGE (10\% polyacrylamide) of Glugea epinephelusis proteins run under reducing conditions and stained with Coomassie Bright Blue. Lanes: $M$, pre-stain molecular weight markers; 1 , intact mature spores $\left(10^{7}\right.$ spores $\left.\mathrm{ml}^{-1}\right) ; 2$, soluble spore proteins $\left(0.5 \mathrm{mg} \mathrm{ml}^{-1}\right)$. (B) Western blot analysis showing the antigens identified by pooled sera of naturally infected fish. Lanes: 1, intact mature spores; 2 , soluble protein 


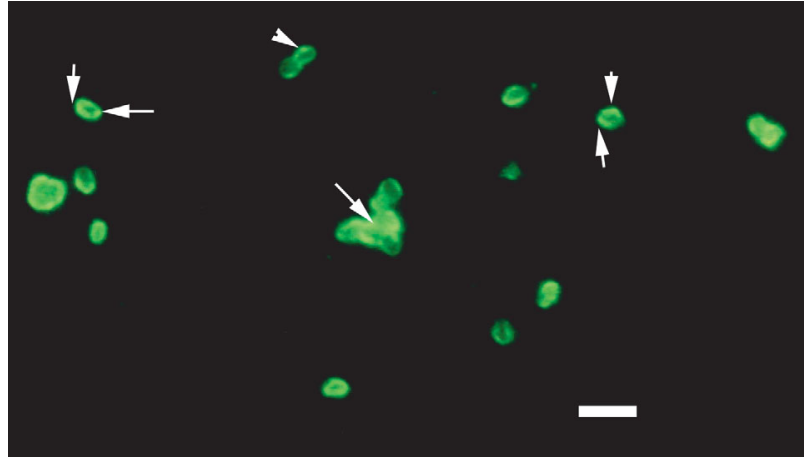

Fig. 4. Epinephelus akaara. Indirect fluorescent antibody tests with polyclonal antibodies of naturally infected grouper, showing strong fluorescence on the surface of the spores, especially the anterior and posterior of the spores (arrowheads). Scale bar $=10 \mu \mathrm{m}$

and sporoplasmic cells during sporogony of Giugea epinephalusis. On the other hand, species-stage antigen might exist in the new microsporidium. If so, these will provide a good basis for diagnosis or therapy of the pathogen.

Gel electrophoresis and immunoblot assay have been widely used to determine the nature of antigenic proteins of parasitic microsporidians, and a speciesspecific array of polypeptides was also demonstrated in some species. The complex pattern of Glugea epinephelusis antigens was identified in the present work and our results showed no similarity to those of previous reports (Irby et al. 1986, Delbac et al. 1998), which indicate that the pathogen is a new species to some extent. More than 9 protein bands were immunogenic to Epinephelus akaara, but further investigations are necessary to determine whether antigens with immunodiagnostic and protective value exist. In addition, an interesting phenomenon was that some immunogenic antigens are not the main protein bands. In fact, some protein bands identified by western blot did not even appear in SDS-PAGE. This phenomenon was also reported by Irby et al. (1986), and will cause problems when producing monoclonal antibodies with the extractable proteins of spores as immunogens. Therefore, the intact mature spore might be a good choice as an immunogen for immunization. The results from SDS-PAGE and western blot were identical with those from cross reaction. Similar antigen components or epitopes between the intact mature spores and the soluble spore proteins were present which can be recognized by the hosts' immune system.

IFAT showed that there are important antigenic determinants in the exospore, especially on the anterior and posterior ends of spores, rather than in internal components of spores, e.g. sporoplasm and polar tube. This suggests that the soluble spore components might come mainly from the spore surface. In addition, it is possible to determine which surface components of Glugea epinephelusis spores are the main immunogen for the host. Although infection mechanisms of microsporidians have been extensively documented (Takvorian et al. 1986, Frixione et al. 1992, Docker et al. 1997, Shaw et al. 1998), no unanimous conclusion about these has been reached so far. It was widely accepted that an extrusion of the polar filaments and the release of sporoplasm in an optimal host environment initiate the infection. But the derivation mechanisms of polar filament extrusions are unknown. On the grounds of the results of the present work, it was speculated that there might be some receptors on the surface of the spores which receive the signal of hosts to activate the germination of microsporidian spores which initiate infection. A further characterization of the surface components of $G$. epinephelusis spores and their role in the germination of the new microsporidium spores and infection of the parasite will be necessary to develop an immunological control and prophylactic vaccination of grouper microsporadiosis.

Acknowledgement. We are very grateful to Dr. Y. S. Lu and Dr. B. J. Sun for critical reading of the manuscript. The research was financially supported by the Project for Knowledge Innovation of the Chinese Academy of Sciences (No. 1999051 and No. KSCX2-1-04) and the National Science Fund of China (30271028).

\section{LITERATURE CITED}

Delbac F, Duffieux F, David D, Metenier G, Vivares C (1998) Immunocytochemical identification of spore proteins in two microsporidia, with emphasis on extrusion apparatus. J Eukaryot Microbiol 45(2):224-231

Docker MF, Devlin RH, Richard J, Khattra J, Kent ML (1997) Sensitive and specific polymerase chain raction assay for detection of Loma salmonae (Microsporea). Dis Aquat Org 29:41-48

Frixione E, Ruiz L, Santillan M, de Vargas LV, Tejero JM, Undeen AH (1992) Dynamics of polar filament discharge and sporoplasm expulsion by microsporidian spores. Cell Motil Cytoskelet 22:38-50

Hung HW, Lo CF, Tseng CC, Kou GH (1996) Humoral immune response of Japanese eel, Anguilla japonica Temminck \& Schlegel, to Pleistophora anguillarum Hoshina, 1951 (Microspora). J Fish Dis 19:243-250

Hung HW, Lo CF, Tseng CC, Kou GH (1997) Antibody production in Japanese eels, Anguilla japonica Temminck \& Schlegel. J Fish Dis 20:195-200

Irby WS, Huang YS, Kawanishi CY, Brooks WM (1986) Immunoblot analysis of exospore polypeptides from some entomophilic Microsporidia. J Parasitol 33(1):14-20

Kawamura A (1977) Fluorescent antibody techniques and their application, 2th edn. University of Tokyo Press, Tokyo

Kim JH, Yokoyama H, Ogawa K, Takahashi S, Wakabayashi $\mathrm{H}$ (1996) Humoral immune response of Ayu, Plecoglossus altivelis to Glugea plecoglossi (Protozoa: Microspora). Fish Pathol 31(4):215-220 
Kim JH, Ogawa K, Wakabayashi H (1998) Respiratory burst assay of head kidney macrophages of Ayu, Plecoglossus altivelis, stimulated with Glugea plecoglossi (Protozoa: Microspora) spores. J Parasitol 84(3):552-556

Kim JH, Ogawa K, Wakabayashi H (1999) Lectin-reactive components of the microsporidian Glugea plecoglossi and their relation to spore phagocytosis by head kidney macrophages of ayu Plecoglossus altivelis. Dis Aquat Org 39:59-63

Laudan R, Stolen JS, Call A (1986) The immune response of a marine teleost, Pseudopleuronectes americanus (winter flounder) to the protozoan parasite Glugea stephani. Vet Immunol Immun 12:403-412

Laudan R, Stolen JS, Call A (1987) The immunomodulating effect of the microsporidian Glugea stephani on the humoral response and immunoglobulin levels in winter flounder, Pseudopleuronectes americanus. J Fish Biol 31:155-160

Leiro J, Estèvez J, Santamarina MT, Sanmartin ML, Ubeira FM (1993) Humoral immune resoponse fo turbot, Scophthalmus maximus (L.), to antigens from Tetramicra brevifilum Matthews \& Matthews, 1980 (Microspora). J Fish Dis 16:577-584

Leiro J, Ortega M, Siso MIG, Sanmartín, Ubeira FM (1997) Effects of chitinolytic and proteolytic enzymes on in vitro phagocytosis of microsporidian by spleen macrophages of turbot, Scophthalmus maximus L. Vet Immunol Immun 59: $171-180$

Pomport-Castillon C, Gasc C, Romestand B (1999) IgM levels and specific antibody activity of the flounder (Platichthys flesus L.), following injection of microsporidian spores.

Editorial responsibility: Wolfgang Körting,

Hannover, Germany
Fish Shellfish Immunol 9:153-156

Roberts R J (2001) Fish pathology, 3rd edn. Harcout Publishers, London

Sambrook J, Fritsch EF, Maniatis T (1989) Molecular cloning: a laboratory manual, 2nd edn. Cold Spring Harbor Laboratory Press, Cold Spring Harbor, NY

Shaw RW, Kent ML, Adamson ML (1998) Modes of transmission of Loma salmonae (Microsporidia). Dis Aquat Org 33:151-156

Takvorian PM, Cali A (1986) The ultrastructure of spores (Protozoa: Microsporida) from Lophius americanus, the angler fish. J Parasitol 33:570-575

Wakelin D. (1996) Immunity to parasites: How parasite infections are controlled, 2nd edn. Cambridge Univeristy Press, Cambridge

Wongtavatchai J, Conrad PA, Hedrick RP (1995) Effect of the microsporidian Enterocytozoon salmonis on the immune response of Chinook salmon. Vet Immunol Immun 48: 367-374

Woo PTK (1992) Immunological responses of fish to parasitic organism. Annu Rev Fish Dis 2:339-366

Wu HB, Wu YS, Wu Z.H. (2005) Occurrence of a new microsporidium in the abdominal cavity of Epinephelus akaara. Acta Hydrobiol Sin 29(2):150-154

Zhang JY, Wu YS, Lu YS, Wang JG (2004) Advance in research of fish microsporidia. Acta Hydrobiol Sin 28(5):563-568

Zhu P, Feng S Z. (1994) Antibody experimental technique, ChangChun Press, Changhun

Submitted: March 24, 2004; Accepted: August 15, 2004 Proofs received from author(s): March 11, 2005 